\title{
The Effect of Project-based Cooperative Studio Studies on the Basic Electronics Skills of Students' Cooperative Learning and their Attitudes
}

\author{
Özgen KORKMAZ \\ Amasya University Technology Faculty Department of Computer Engineering, Amasya, Turkey \\ Email: ozgenkorkmaz@gmail.com
}

Received: 30 March 2018; Accepted: 10 April 2018; Published: 08 May 2018

\begin{abstract}
Engineering education plays a prominent role in the development of technologies, society, nation, production, economy and employment. It is the art of applying scientific and mathematical principles, and experience to produce a technical product or system to meet out a specific need in the society. Based on the literature, it was thought that implementation of a cooperative project-based education on electricalelectronics engineering students could contribute to their basic engineering skills, their cooperative learning, and their attitudes towards engineering education and occupation. The aim of this study was to reveal the effect of project-based cooperative studio studies on the occupational basic skills of electrical-electronics engineering students, cooperative learning, and their attitudes towards engineering occupation. The research is designed to be a study that is half-experimental and halfquantitative study and was composed of 42 students. Within the research, project-based cooperative studio studies were utilized by the experimental group while the control group had similar course requirements for six weeks, but their practice solely included the content of the Lab II course in the official curriculum. The resulting data was gathered using the Basic Electronics Skills SelfEffacement Scale, the Scale for Attitude towards Cooperative Learning, and the Scale for Attitude towards Engineering and Engineering Education. The results indicate that the project-based cooperative studio studies are contributing more meaningfully to students' intermediate level electronics skills, and their attitudes towards cooperative learning and towards engineering occupation.
\end{abstract}

Index Terms-Project-based learning, cooperative learning, occupational attitudes, basic electronics skills, engineering education.

\section{INTRODUCTION}

According to Dahiya and Nehra [1] engineering education plays a prominent role in the development of technologies, society, nation, production, economy and employment. It is the art of applying scientific and mathematical principles, and experience to produce a technical product or system to meet out a specific need in the society [1]. In this context the foundation of the programming of engineering education is to bring a theoretical foundation and the basic skills of specific engineering areas together, fundamental engineering formation consists of engineering mathematics, general physics, general chemistry related to the area, drawing, and other fundamental courses designed to enhance innovative thinking. Occupational basic skills include laboratory implementations of the given theoretical courses. The laboratory implementations for enabling theoretical knowledge are very important during the engineering education process. The laboratory courses introduce these skills are traditionally conducted in a manner such that a predefined task is assigned to the students, and most of the time guidance is left to the teaching assistants. Yet, it is essential to plan these very important implementations better and more efficiently. It is a fact that engineers are constantly obliged to work on projects with project groups during their occupational development; thus, utilization of cooperative learning and project-based learning approaches can make a considerable contribution to the development of basic engineering skills and project-based and cooperative working skills. Cooperative learning enables students to maintain a constant level of engagement and connect their knowledge with the outside world [2]. In their study, Justus and Sirajudin [3] concluded that the project-based teaching-learning program can be applied in small and medium-sized developmental units.

Based on the above, it was thought that implementation of a cooperative project-based education on electricalelectronics engineering students could contribute to their basic engineering skills, their cooperative learning, and their attitudes towards engineering education and occupation; for this reason, the aim of this study is to reveal the effect of project-based cooperative studio studies on the basic occupational skills of ElectricalElectronics Engineering students, on cooperative learning, 
and their attitudes towards the engineering occupation.

The later part of the paper is organized in the following way. In the II. Section, project-based learning and cooperative learning related studies in the literature. are summarized. In the III. Section, the pattern, study group, data collection tools, experimental process and data analysis methods used in the research is described. In the IV. section, the findings and Interpretation obtained from the analyses made on the collected data were discussed. In the last section, the results were discussed.

\section{RELATED WORKS}

In the literature, there are studies on the positive effects of cooperative learning on the academic success of students and on their social development, thinking ability, self-confidences, learning skills, metacognition levels, problem solving abilities, positive attitude towards studying in a group, positive attitude towards learning and their courses, and internal motivations. [4-13]. There are some requirements for each learning method to be successful. The success of cooperative learning is dependent on the contributions of each member of the group activity. Some important requirements for an effective cooperative learning environment are positive interdependence, personal commitment and equal personal contribution $[9,12]$. In the literature, it is stated that the students are reluctant to actively participate in group studies, and this situation is worrisome in terms of the success of cooperative learning process [9, 14]. Sometimes only a few eager students undertake the work at hand, and the rest of the students thus evade their responsibilities. In such situations, it becomes very difficult to evaluate the personal contributions of the students to the group product. In such circumstances, the difficulties in evaluating group members individually can become one of the biggest problems in front of the cooperative learning activities in the classroom [9]. In a study by Korkmaz and Yeşil [14], they state that the fundamental reason underlying the unwillingness to participate in group studies is this situation. This situation may also negatively affect the three provisions that play a key role in the success of cooperative learning. This problem can be solved if each group member contributes equally. According to Beltadze [15] for the success of the group it is desirable that the sympathy of the teacher was expressed for the absolute majority of the members of the group and the lesser are others much more is the benefit of a pedagogue and of the group itself. So as again with allowance of the human validities, existence even of one student in the group of so called second category influences on the successes of the whole group. To make student activities easier and to develop the cooperative activities in a constructivist perspective parallel to the modern educational approaches, internet-based information technologies offer several tools [16]. According to Altun [17] the cooperation learning environment of the study provided cooperative learning environment, supported permanent learning, provided opportunities to be successful, contributed to the development of social and personal skills, but caused students to worry as it requires students to be successful at all stages. In the literature it is possible to come across many researches that support the findings. It has been found out that cooperative learning has important effects on improving academic achieve of students [18-20], and developing motivation [21, 22], and improving collaborative working ability [23].

There are many studies in the literature about the effectiveness of project-based learning which develops advanced cognitive skills of the participating students including problem solving, decision-making, etc., and it enables their feeling of responsibility through their physical and social environments [24]. Furthermore, project-based learning may create and enhance the students' thinking skills. The students' active participation in the project process helps them form their own opinions and reveal their perspectives [25].

Hamurcu [26] expresses the advantages of projectbased education approach as follows:

- Enhancing and enriching the learning skills of the students.

- Providing lifelong learning.

- Ensuring participation in group works and cooperation-based learning activities.

- Suggesting many ways for the students to reflect their knowledge and participate.

- Allowing the usage of different dimensions of the intelligence (kinesthetic, spatial, logic, language vb.) Gives meaningful information to the family, teacher and school management about the student. Students associate the products they produce in real life with their performances.

- Developing problem solving skills and problembased learning skills.

- Finding an opportunity to apply the knowledge they obtain via projects on different topics.

Project-based learning gives students various skills, according to Vatansever Bayraktar [27]. These include:

- Vital Skills: managing a meeting, preparing a budget, planning, etc.

- Technology Using Skills: using information technologies

- Cognitive Process Skills: decision-making, critical thinking skills, problem solving

- Self-Control Skills: building aims, organizing the operations, time-management

- Attitudes: interest in learning, curiosity through the education for the future

- Tendencies: self-control, feeling of success

- Beliefs: self-sufficiency

Project based learning is one of the most important strategies for active learning [28]. In addition, Project based learning is an innovative approach where students drive their own learning through inquiry, standards alignment, and collaborative research $[29,30]$. Research 
conducted by Nielsen et al. [31] found that project-based learning is an effective teaching model for engineering education students. The engineering students were able to achieve process skills and reported felt more motivated to learn actively engage the outside sources to accomplish the requirements of the Project [28]. It has been found out that project-based learning has important effects on students' academic achievement [32, 33], and to students' individual learning [34], and students' motivation, their capability in problem solving and their learning achievement [35].

\section{A. Problem Sentence}

Do project-based cooperative studio studies have any effects on the electrical-electronics engineering students' occupational basic skills, cooperative learning, and attitudes towards engineering occupation of?

\section{B. Sub-problems}

(1) Are the groups equal in terms of their basic engineering skills, attitudes towards cooperative learning, and engineering occupation before implementation?
(2) Do project-based cooperative studio studies make a more meaningful contribution to the basic electronics skills of the students than the traditional method?

(3) Do project-based cooperative studio studies make a more meaningful contribution to the attitudes of the students towards cooperative learning than the traditional method?

(4) Do project-based cooperative studio studies make a more meaningful contribution to the attitudes of the students towards engineering and engineering education than the traditional method?

\section{METHODS}

\section{A. Research Design}

This study is a pre-test/post-test control grouped halfexperimental and quantitative character study. The graphical projection of the test model used in the research is as follows:

Table 1. Experimental Design

\begin{tabular}{|c|c|c|c|}
\hline Groups & Pretest & Experimental manipulation & Posttest \\
\hline Experimental Group & \multirow{2}{*}{$\begin{array}{l}\text { - Basic Electronics Skills Self- } \\
\text { Efficacy Scale } \\
\text { - Attitude Scale towards } \\
\text { Cooperative Learning } \\
\text { - Attitude Scale towards } \\
\text { Engineering and Engineering } \\
\text { Education }\end{array}$} & $\begin{array}{l}\text { Project-based cooperative studio } \\
\text { studies }\end{array}$ & \multirow[t]{2}{*}{$\begin{array}{l}\text { - } \text { Basic Electronics Skills Self- } \\
\text { Efficacy Scale } \\
\text { - Attitude Scale towards } \\
\text { Cooperative Learning } \\
\text { - Attitude Scale towards } \\
\text { Engineering and Engineering } \\
\text { Education }\end{array}$} \\
\hline Control Group & & $\begin{array}{l}\text { Traditional } \\
\text { application }\end{array}$ & \\
\hline
\end{tabular}

\section{B. Study Group}

42 students, 11 females and 31 males, continuing their 3rd year in the Amasya University Faculty of Technology Electrical-Electronics Engineering, constitute the study group of this research. All participants were volunteers. Distribution of the students in the study groups is summarized in Table 2.

Table 2. Distribution of Study Groups with respect to Gender

\begin{tabular}{cccc}
\hline Groups & Male & Female & Total \\
\hline Test group & 3 & 19 & 22 \\
\hline Control Group & 8 & 12 & 20 \\
\hline Total & 11 & 31 & 42 \\
\hline
\end{tabular}

\section{Experimental Process}

Experimental Group: The experimental group was divided into five groups each consisting of four people and designed as project groups. Before implementation, the students are given methodological information about the implementation.

The experiment was implemented in the Faculty of Technology Robotics Laboratory. In the first stage of the implementation, the project-based cooperative learning implementation and the expectation from the students were explained, and students volunteered to build cooperative learning groups. After that, each group drew lots for one of the following projects as a task: hexacopter, 3-D printer, mini sumo, and line follower. Students were introduced to the projects and examples and then were tasked with completing the following stages:

- Gather detailed information related to the project

- Detect the necessary materials for the project

- Build the circuit schematic

- Designate specifically how the project will be done

- Present the project

- Acquire circuit components and design after approval of the project

- Do programming and controls

- Activate and run the project

At each step of the project-based learning process summarized above, the students were provided with guidance but there was no direct interference. The projects lasted six weeks, but the amount of weekly study hours was left entirely to the individual groups' decision. The products resulting from the project studies are presented in Figure 1. 


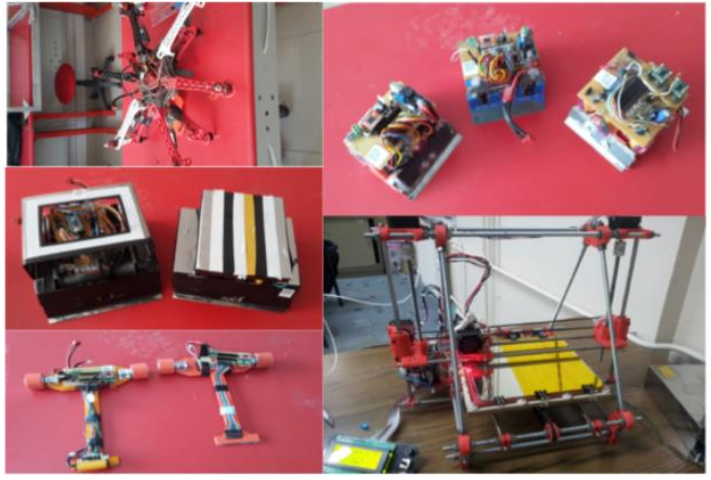

Fig.1. Products generated by the project studies

Control Group: A similar implementation was applied to the control group for six weeks, but their implementation is included in only the content of Lab II course in the official curriculum. The implementations in the course content include experiments to be done individually and with group, and the experiment reports prepared after the experiments are done. In this course, the following predefined experiments were done:

- Amplifier with transistor experiment

- DC and AC FET analysis experiment

- OPAMP (Operational Amplifiers) experiment

- 555 IC application

- Oscillator (Wien Bridge asc) experiment

\section{Data Collection Tool}

a. Basic Electronics Skills Self-Efficacy Scale: This scale is a BESS five- degree Likert-type scale consisting of 19 items that can be gathered under two factors. The factors were named regarding the general characteristics of the items under them. When the skill groups were analysed under this frame, Factor 2 includes basic electronics skills (eigenvalue: 2,384, announced variance: \%25,8) and Factor 1 includes intermediate level skills (eigenvalue: 7,633, announced variance: \%26,9). Basic level skills involve the fundamental courses that the students take in their first year and the fundamental practices they perform in their second year; intermediate level skills involve the more complicated skills that the students acquire in the third year of their education. Basic and intermediate level skills are common skills; therefore, they are involved in this scale.

The validity of the scale was analysed via two different methods, factor analysis and distinctiveness characteristics. To evaluate how much each item on the scale can measure the factor they belong to, item total factor correlations and corrected correlations are calculated on the data. According to the acquired values, each item and each factor in the scale are found to serve the run of the scale and the aim to scale the desired facility at a meaningful level. In addition, the $t$ value related to the differences between the top $27 \%$ and bottom $27 \%$ groups was analysed, and the item distinctiveness's was researched, and it was detected that the distinctiveness of both of the run-of the scale and each of the items is high; in other words, it was detected that each item is distinctive at the desired level. Internal consistency coefficients are calculated using two congruent halves (0.880), Cronbach Alpha (0.915), the Sperman-Brown (0.878) formula, and the Guttmann splithalf reliability formula (0.753). With these values calculated, it was concluded that the scale could make reliable scaling.

b. Attitude Scale towards Cooperative Learning: To scale the cooperative learning-based attitudes of the students, the Scale for Attitude towards Cooperative Learning developed by McLeish [36] and adapted to Turkish by Altun and Korkmaz [37] was used. According to the adaptation analysis done by Altun and Korkmaz [37], the scale consists of eight items, is one-dimensional, and of type five-degree Likert. This one dimension explains $60,217 \%$ of the total variance. The internal consistency coefficient is 0.883 (Cronbach's Alpha). Thus, it is seen that this is a valid and reliable scale that can reveal the students' attitudes towards cooperative learning in the Turkish culture.

c. Attitude Scale towards Engineering and Engineering Education: In this study, in order to scale the students' attitudes towards the occupation of engineering and the engineering education they receive, the Scale for Attitude Towards Engineering and Engineering Education (EEAS), which was developed and tested in terms of reliability and validity by Korkmaz, Kösterelioğlu, \& Kara [38] was used. EEAS is a five-degree Likert-type scale and consists of 17 items that can be grouped under two factors. Under the first factor, "Attitude towards the Engineering Occupation," nine items are grouped, and under the second factor "Attitude towards Engineering Education," eight items are grouped. The rotated factor loads of each item are between 0.525 and 0.803 . When the contribution of each factor to the announced variance was calculated, the first factor was seen to contribute $23.07 \%$ (eigenvalue: 5.812), and the second factor was found to contribute $21.286 \%$ (eigenvalue: 1.728). The Cronbach Alpha internal consistency coefficient of the scale is 0.765 for the first factor, 0.769 for the second factor, and 0.853 for the whole scale.

\section{E. Analysis of Data}

The scores obtained in from the answers that the data collection tools gave to the five-degree Likert scales did not display a standard characteristic because of the difference in the item numbers of the sub-factors. For this reason, the transformation of these points to standard points, with the lowest 20 and highest 100, was considered appropriate. The data gathered was analysed using arithmetic mean, standard deviation, and $\mathrm{t}$ and Anova analysis.

\section{FINDINGS AND INTERPRETATION}

\section{A. Findings about the Equality of the Groups before Implementation}

It is shown in Table 3 whether the groups are equal in terms of basic electronics skills and their attitudes 
towards engineering and engineering education before implementation of the study.

Table 3. Findings as Regards the Equivalence of Groups

\begin{tabular}{|c|c|c|c|c|c|c|c|}
\hline Variables & & $\mathbf{N}$ & $\overline{\mathbf{X}}$ & S.S & $t$ & df & $\mathbf{p}$ \\
\hline \multirow{2}{*}{ Intermediate Electronic Skills } & Control Gr & 20 & 39.6 & 9.4 & \multirow{2}{*}{-3.179} & & \multirow{2}{*}{0.003} \\
\hline & $\frac{\text { Test Gr }}{\text { Control Gr }}$ & $\frac{22}{20}$ & $\begin{array}{l}56.5 \\
55.9\end{array}$ & $\frac{22.1}{21.7}$ & & & \\
\hline Basic Level Electronic Skills & Test Gr & 22 & 68.5 & 22.2 & -1.857 & & 0.071 \\
\hline \multirow{2}{*}{$\begin{array}{l}\text { Attitudes Towards Cooperative } \\
\text { Learning }\end{array}$} & Control Gr & 20 & 89.6 & 7.4 & \multirow{2}{*}{1.021} & & \multirow{2}{*}{0.312} \\
\hline & Test Gr & 22 & 85.8 & 14.9 & & 40 & \\
\hline \multirow{2}{*}{$\begin{array}{l}\text { Attitudes Towards the Engineering } \\
\text { Profession }\end{array}$} & Control Gr & 20 & 76.2 & 7.8 & \multirow{2}{*}{-1.143} & & \multirow{2}{*}{0.260} \\
\hline & Test Gr & 22 & 78.5 & 5.7 & & & \\
\hline \multirow{2}{*}{$\begin{array}{l}\text { Attitudes Towards the Engineering } \\
\text { Education }\end{array}$} & Control Gr & 20 & 51.3 & 4.7 & \multirow{2}{*}{-1.201} & & \multirow[t]{2}{*}{0.237} \\
\hline & Test Gr & 22 & 53.1 & 5.7 & & & \\
\hline
\end{tabular}

When Table 3 is examined, a meaningful difference is evident between the intermediate level electronics skills of the experimental group and the control group [ $\mathrm{t}_{(2-40)}$ $=3,1179 ; \mathrm{p}<0,05)]$, but there is not a meaningful difference seen between the other levels of skills. Accordingly, it can be said that the groups are equal in terms of the skills other than the intermediate level skills. However, there is not a visible meaningful difference, but when the averages are examined, there is a differentiation seen between the experimental group and control group, and the $t$ value is seen to be bigger than 1 . To bring these differentiations under control, pre-test/post-test difference scores are used in the analyses below.

\section{B. The Effect of Project-Based Cooperative Studio Studies}

The findings about whether there is any difference between the project-based cooperative studio studies and traditional laboratory implementation in terms of intermediate and basic level electronics skills, attitude towards cooperative learning, and attitude towards engineering and engineering education are summarized in Table 4.

Table 4. Effectiveness of Project Based Cooperative Workshop

\begin{tabular}{|c|c|c|c|c|c|c|c|}
\hline Variables & & $\mathbf{N}$ & $\overline{\mathbf{X}}$ & S d & $\mathbf{t}$ & df & $\mathbf{p}$ \\
\hline \multirow{2}{*}{ Intermediate Electronic Skills } & Control Gr & 20 & 10.3 & 11.1 & \multirow{2}{*}{-2.181} & & \multirow{2}{*}{0.035} \\
\hline & Test Gr & 22 & 23.6 & 26.2 & & & \\
\hline \multirow{2}{*}{ Basic Level Electronic Skills } & Control Gr & 20 & 17.7 & 16.2 & \multirow{2}{*}{0.142} & & \multirow{2}{*}{0.975} \\
\hline & Test Gr & 22 & 17.6 & 15.4 & & & \\
\hline \multirow{2}{*}{$\begin{array}{l}\text { Attitudes Towards Cooperative } \\
\text { Learning }\end{array}$} & Control Gr & 20 & 2.7 & 9.7 & \multirow{2}{*}{-2.501} & & \multirow{2}{*}{0.017} \\
\hline & Test Gr & 22 & 10.2 & 9.7 & & 40 & \\
\hline \multirow{2}{*}{$\begin{array}{l}\text { Attitudes Towards the Engineering } \\
\text { Profession }\end{array}$} & Control Gr & 20 & 2.4 & 7.69 & \multirow{2}{*}{-1.931} & & \multirow{2}{*}{0.051} \\
\hline & Test Gr & 22 & 6.1 & 6.4 & & & \\
\hline \multirow{2}{*}{$\begin{array}{l}\text { Attitudes Towards the Engineering } \\
\text { Education }\end{array}$} & Control Gr & 20 & 3.8 & 7.1 & \multirow{2}{*}{-1.452} & & \multirow{2}{*}{0.154} \\
\hline & Test Gr & 22 & 6.7 & 6.1 & & & \\
\hline
\end{tabular}

When Table 4 is examined, it is seen that the projectbased cooperative studio studies differentiate the intermediate level electronics skills $\left[\mathrm{t}_{(2-40)}=2,181\right.$, $\mathrm{p}>0,05)]$, attitude towards cooperative learning $\left[\mathrm{t}_{(2-40)}=-\right.$ 2,5011, $\mathrm{p}>0,05)]$; however, it does not result in differentiation in the basic electronics skills and attitudes towards engineering education. When the averages are examined for intermediate level electronics skills, the average of the experimental group is 23.6, and the average of the control group is 13.3. The score averages of the attitude towards cooperative learning are 10.2 for the experimental group and 2.7 for the control group. The score averages of the attitude towards engineering occupation are 6.1 for the experimental group and 2.4 for the control group. It is seen that these meaningful differentiations are in favor of the experimental group. Accordingly, it can be said that project-based cooperative studio studies contribute meaningfully more to the intermediate level electronics skills and the attitudes towards cooperative learning and towards engineering occupation of the students.

\section{RESULTS AND DISCUSSION}

Project-based cooperative studio studies contribute meaningfully more to the intermediate level electronics skills and the attitudes towards cooperative learning and towards engineering occupation of the students. Today, cooperative learning attracts much more attention because of several contributions to academic success in the environment of learning and teaching, information sharing, and the building of positive social relationships. 
The cooperative learning method, which is counted as one of the modern educational methods, is one of the most original examples of group work. Cooperative learning is an active learning-oriented approach. Active learning is a student-centered approach. Student-centered learning environment makes the students more responsible for their own learning, and thus the students become active constructors rather than passive recipients of knowledge [39]. According to Dahiya and Nehra [1] adopting active learning techniques during course of teaching foundation courses and core courses such as problem/project-based learning, collaborative learning, active listening, active writing, active reading, brainstorming, utilizing software tools and role-playing enables students in thoroughly understanding and effectively mastering subject matter.

Cooperative learning can be described as small group practices in which the students put in effort to move themselves and their friends to the highest level [12]. Cooperative learning is accepted as effective at every level of education and is an education method that is generally preferred [6]. The word "project" means draft or draft development, imagination, planning; it can also have the meaning "construction." Hence, project-based learning appears before use as learning comprehension based on draft development, imagination, planning, and construction [40]. In project-based learning comprehension, as a requirement of a draft-based and process-based structure, learning means the reorganization of the cognitive structure of the learner. A project allows students to take the initiative, make choices about taking responsibility, make decisions, follow their desires and aims; and it prepares a suitable environment for these elements. The students have a desire to study together in and out of the school for the project. Some research results claim that education based on systematic study develops academic success [41]. Good study habits require features such as a suitable study environment, self-authorship, time and stress management, effective rest, and effective reading [42]. When all of these are considered, it is seen that it is natural for project-based cooperative studio studies to contribute to the acquisition of intermediate level electronics skills of the students more effectively than the traditional method. Since advanced level skills arise as a result of branching, they were not included in this research. Because the students did all the activities as group work in a cooperative environment in this projectbased experimental implementation, the students noticed the importance of group work and developed more positive opinions; this also might have been given rise to this meaningful contribution. Moreover, since the solid products that appeared at the end of these studies provided occupational satisfaction to the students, this may have reinforced the positive feelings of the students about the engineering occupation.

Project-based cooperative studio studies do not differentiate the basic level electronic skills of the student. The fact that the students in both the experimental and control groups had taken courses in basic level electronics skills, and since intermediate level skills occur with the development and reinforcement of these basic skills, this may have resulted in this non-formation of differentiation. On the other hand, when the fact that project-based cooperative studio studies are being used with the aim of developing intermediate and advanced level skills, this result can be said to quite satisfactory.

Project-based cooperative studio studies do not contribute to the attitudes of the students towards engineering education. Engineering education involves several theoretical and implementation studies over four years. A six-week experimental implementation may have been inadequate for changing attitudes towards the whole process.

Considering that project-based cooperative studio studies contribute meaningfully more to intermediate level electronics skills, attitudes towards cooperative learning, and attitudes towards engineering occupation, it can be suggested that, in the electronics laboratory courses in electronics education, instead of the traditional laboratory education consisting of predefined experiments, group activities based on the project tasks requiring the same skills should be preferred.

\section{ACKNOWLEDGEMENT}

This research was executed within the scope of the SEB-BAP 15-068 project endorsed by the Amasya University Project Coordination Unit of Scientific Research.

\section{REFERENCES}

[1] S. Dahiya, V. Nehra, "Ensuring Employment and Employability through Electronics Engineering Education: A Case Study of BPS Women University”, IJMECS, vol.7, no.11, pp.35-52, 2015. DOI: 10.5815/ijmecs.2015.11.05

[2] A. A. Alkhathlan, A.A. Al-Daraiseh, "An Analytical Study of the Use of Social Networks for Collaborative Learning in Higher Education", International Journal of Modern Education and Computer Science(IJMECS), Vol.9, No.2, pp.1-13, 2017. DOI: 10.5815/ijmecs.2017.02.01

[3] S. Justus, M. Sirajudin, "Evaluating the Project based Organizational Teaching-Learning Process", International Journal of Modern Education and Computer Science(IJMECS), Vol.5, No.5, pp.38-48, 2013.DOI: 10.5815/ijmecs.2013.05.05

[4] K. Hew, W. Cheung "Attracting student participation in asynchronous online discussions: a case study of peer facilitation", Computers \& Education, 51(3), 1111-1124, 2008, Doi:10.1016/j.compedu.2007.11.002

[5] A. Jones, K. Issroff, "Learning technologies: affective and social issues in computer-supported collaborative learning", Computers \& Education, 44(4), 395-408. 2005, Doi: 10.1016/j.compedu.2004.04.004

[6] D. W. Johnson, R. T. Johnson, K. Smith, "The state of cooperative learning in postsecondary and professional settings", Educational Psychology Review, 19(1), 15-29, 2007,Doi: 10.1007/s10648-006-9038-8

[7] T. Kumaran, "The effects of cooperative learning on preschoolers' mathematics problem-solving ability", Educational Studies in Mathematics, 72,325-340, 2009, Doi 10.1007/s10649-009-9197-x. 
[8] Y. Law, "The effects of cooperative learning on enhancing Hong Kong fifth graders' achievement goals, autonomous motivation and reading proficiency", Journal of Research in Reading, 34(4), 402-425, 2011, Doi: 10.1111/j.1467-9817.2010.01445.x

[9] C.W. Nam, R. D Zellner, "The relative effects of positive interdependence and group processing on student achievement and attitude in online cooperative learning", Computers \& Education, 56, 680-688, 2011, Doi:10.1016/j.compedu.2010.10.010

[10] Y. Sharan, "Cooperative learning for academic and social gains: valued pedagogy, problematic practice", European Journal of Education, 45(2), 300-21, 2010, Doi:10.1111/j.1465-3435.2010.01430.x

[11] D. Wang, S. S. J. Lin, C. Sun. "DIANA: A computersupported heterogeneous grouping system for teachers to conduct successful small learning groups", Computers in Human Behavior, 23, 1997-2010, 2007, Doi:10.1016/j.chb.2006.02.008.

[12] S. Veenman, B. Kenter, K. Post. "Cooperative learning in Dutch primary classrooms", Educational Studies, 26(3), 281-302, 2000,

[13] E. Zhi, F. Liu. Colloquium, "Developing a personal and group-based learning portfolio system", British Journal of Educational Technology, 38 (6), 1117-1121, 2007.

[14] Ö. Korkmaz, R. Yesil, "Evaluation of achievement, attitudes towards technology using and opinions about group work among students working in gender-based groups", Gazi University Journal of Gazi Education Faculty, 31(1), 201-229, 2011.

[15] G. N. Beltadze, "Game Theory - basis of Higher Education and Teaching Organization", International Journal of Modern Education and Computer Science(IJMECS), Vol.8, No.6, pp.41-49, 2016. DOI:10.5815/ijmecs.2016.06.06

[16] M. Biasutti, "The student experience of a collaborative elearning university module", Computers \& Education, 57, 1865-1875, 2011, Doi:10.1016/j.compedu.2011.04.006.

[17] S. Altun, "The Effect of Cooperative Learning on Students' Achievement and Views on the Science and Technology Course", International Electronic Journal of Elementary Education, 7(3), 451- 468, 2015.

[18] A. Zaheer, M. Nasir, "Effects of cooperative learning vs. traditional instruction on prospective teachers' learning experience and achievement", Journal of Faculty of Educational Sciences, 43(1), 151-164, 2010.

[19] G. Çapar, "İşbirlikli öğrenme yönteminin öğrencinin matematik başarısı ve matematiğe ilişkin tutumu üzerindeki etkililiği: Bir meta-analiz çalismasi [Cooperative learning method's effect on student's mathematics achievement and relevant behavior: A metaanalysis study]", Çukurova University, Social Science Enstitute, 2011.

[20] Q. Parveen, S. Batool, "Effect of cooperative learning on achievement of students in general science at secondary level", International Education Studies, 5(2), 154-158, 2012.

[21] M. Kus, E. Filiz, S. Altun, "Teacher and student thoughts on effectiveness of cooperative learning in geography teaching", Educational Research and Reviews, 9(11), 312319, 2014.

[22] H. Yoshida, S. Tani, T. Uchida, J. Masui, A. Nakayama, Effects of online cooperative learning on motivation in learning Korean as a foreign language", International Journal of Information and Education Technology, 4(6), 473-477, 2014
[23] B. Rienties, D. Tempelaar, P.V. den Bossche, W. Gijselaers, M. Segers, "The role of academic motivation in Computer-Supported Collaborative Learning", Computers in Human Behavior, 25(6), 1195-1206, 2009.

[24] J. Y. Dori, T. Tal, "Revital. Formal and Informal Collabarate Projects: Engaging in Industry with Environmental Awareness", Science Education, 84(1), 95$113,2000$.

[25] H. U. Zoller, "Problem Solving and the "Problem Solving Paradox" in Decision Making Oriented Environimental Education, InKeiny, S. and Zoller, U. (Eds), Conceptual Issues in Enviromental Education, New York: Peter Lang. Pub, 1991.

[26] H. Hamurc, "Project-Based Science Education Approach in Pre-school Education", 4. Science Eduation Conference, Ankara, Turkey, 2000

[27] H. Vatansever Bayraktar "Project based learning approach", The Journal of International Social Research, 8(37), 2015.

[28] D. H. Iwamoto, J. Hargis, ispepiK. Vuong. "The Effect of Project-Based Learning on Student Performance: An Action Research Stud" International Journal for the Scholarship of Technology Enhanced Learning, 1(1): 2442, 2016.

[29] S. Bell, "Project-based learning for the 21st century: Skills for the future", Clearing House, 83(2), 39-43, 2010. Doi:10.1080/00098650903505415

[30] T. Markham, J.Larmer, K. Ravitz, "Project based learning handbook: A guide to standards-focused project based learning for middle and high school teachers (2nd ed.)". Novato, CA: The Buck Institute for Education, 2003. isEP:

[31] J. D. Nielsen, X. Y. Du, A.A. Kolmos, "Innovative application of a new PBL model to interdisciplinary and intercultural projects", International Journal of Electrical Engineering Education, 47(2), 174-188, 2010

[32] D. E. Kanter, "Doing the project and learning the content: Designing project-based science curricula for meaningful understanding", Science Education. 94 (3), 525- 551, 2010.

[33] J. L. Shih, C.W. Chuang, G.J. Hwang, "An inquiry- based mobile learning approach to enhancing social science learning effectiveness", Educational Technology \& Society, 13(4), 50-62, 2010.

[34] C.C. Chang, K.H. Tseng, "Using a Web-based portfolio assessment system to elevate project-based learning performances", Interactive Learning Environments, 19(3), 211-230, 2011

[35] C.M. Hung, G.J. Hwang, I. Huang, "A Project- based Digital Storytelling Approach for Improving Students' Learning Motivation, Problem-Solving Competence and Learning Achievement", Educational Technology \& Society, 15 (4), 368-379, 2012.

[36] K. McLeish, "Attitude of students towards cooperative learning methods at knox community college: A descriptive study", Unpublished Master Thesis. University of Technology, Jamaica, 2009, Eric Nu: ED506779.

[37] Halis Altun, Özgen Korkmaz. "Computer and Electrical \& Electronic Engineering Students' Attitude Towards Cooperative Learning", AWER Procedia Information Technology \& Computer Science. [Online], 4:329-334, 2012, Available from: http://www.world-educationcenter.org/index.php/P-ITCS. Proceedings of 3rd World Conference on Information Technology (WCIT-2012), 14-16 November, University of Barcelon, Barcelona, Spain. 
[38] Ö. Korkmaz, M. Kösterelioğlu, M Kara, “A Validity and Reliability Study of the Engineering and Engineering Education Attitude Scale (EEAS)". On press., 2018.

[39] S. Fatima, S. Abdullah. "Improving Teaching Methodology in System Analysis and Design using Problem Based Learning for ABET. International Journal of Modern Education and Computer Science(IJMECS), Vol.5, No.7, pp.60-68, 2016. DOI:10.5815/ijmecs.2013.05.07

[40] M. Erdem, "Project Based Learning", Journal of Hacettepe University Educational Faculty, 22: 172-179, 2002.

[41] D. Kember, "Learning Approaches, Study Time and Academic Performance", Higher Education, 9(3):329-343, 1995.

[42] H. Korkmaz, F. Kaptan, "The Effects of Project-Based Learning on Elementary School Students' Academic Achievement, Academic Self Concepts and Study Time in Science Education", Journal of Hacettepe University Educational Faculty, 22: 91-97, 2002.

\section{Authors' Profiles}

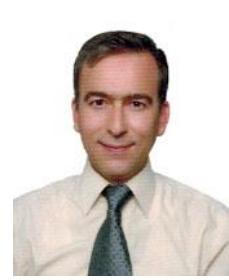

Özgen KORKMAZ was born in Konya in 1972. He graduated from Faculty of Industrial Arts Education and started teaching at Gazi University Department of Computing in 1993. He completed his MA degree in Science Institute Department of Computer Education at Afyon Kocatepe University. In 2007, he completed his PhD at the Institute of Educational Sciences, Department of Educational Technology at Gazi University. He is currently working as an Associate Professor at Amasya University, Faculty of Technology, Department of Computer Engineering. His research interests include computer programming, webbased learning, blended learning, message design and webbased programming technologies.

How to cite this paper: Özgen KORKMAZ, " The Effect of Project-based Cooperative Studio Studies on the Basic Electronics Skills of Students' Cooperative Learning and their Attitudes", International Journal of Modern Education and Computer Science(IJMECS), Vol.10, No.5, pp. 1-8, 2018.DOI: 10.5815/ijmecs.2018.05.01 